\title{
Epidemic Network Analysis for Mitigation of Invasive Pathogens in Seed Systems: Potato in Ecuador
}

\author{
C. E. Buddenhagen, † J. F. Hernandez Nopsa, K. F. Andersen, J. Andrade-Piedra, G. A. Forbes, P. Kromann, \\ S. Thomas-Sharma, P. Useche, and K. A. Garrett ${ }^{\dagger}$
}

First, second, third, and ninth authors: Plant Pathology Department, Institute for Sustainable Food Systems, and Emerging Pathogens Institute, University of Florida, Gainesville 32611; fourth and fifth authors: International Potato Center, Lima, Peru; sixth author: International Potato Center, Quito, Ecuador; seventh author: Plant Pathology Department, Kansas State University, Manhattan 66506; and eighth author: Food and Resource Economics Department, University of Florida.

Current address of S. Thomas-Sharma: Department of Plant Pathology, University of Wisconsin-Madison, Madison 53704.

Accepted for publication 13 July 2017.

\begin{abstract}
Seed systems have an important role in the distribution of high-quality seed and improved varieties. The structure of seed networks also helps to determine the epidemiological risk for seedborne disease. We present a new approach for evaluating the epidemiological role of nodes in seed networks, and apply it to a regional potato farmer consortium (Consorcio de Productores de Papa [CONPAPA]) in Ecuador. We surveyed farmers to estimate the structure of networks of farmer seed tuber and ware potato transactions, and farmer information sources about pest and disease management. Then, we simulated pathogen spread through seed transaction networks to identify priority nodes for disease detection. The likelihood of pathogen establishment was weighted based on the quality or quantity of information sources about disease management.
\end{abstract}

ABSTRACT
CONPAPA staff and facilities, a market, and certain farms are priorities for disease management interventions such as training, monitoring, and variety dissemination. Advice from agrochemical store staff was common but assessed as significantly less reliable. Farmer access to information (reported number and quality of sources) was similar for both genders. However, women had a smaller amount of the market share for seed tubers and ware potato. Understanding seed system networks provides input for scenario analyses to evaluate potential system improvements.

Additional keywords: ERGM, seed degeneration, vegetatively propagated crops, virus.
Networks of crop seed distribution are an important factor in determining the success of agricultural systems. They drive the spatial distribution of crop plant genotypes and disease resistance genes, as well as the spread of seedborne disease. Seed systems encompass biophysical elements as well as all the stakeholders and activities that support the system, including interacting scientific (e.g., breeding and extension), management (e.g., agricultural practices and integrated pest management [IPM]), and regulatory (e.g., legally certified seed standards) components (Almekinders et al. 2007; Devaux et al. 2014; Jaffee et al. 1992; Kromann et al. 2017; Thiele 1999; Thiele et al. 2011). Thus, seed systems are best understood as a network of interacting biophysical and socioeconomic elements (Leeuwis and Aarts 2011). Establishing new seed systems has often been challenging, especially in low-income countries, probably due, in part, to the many system components that must dovetail for seed system success. We propose a framework to improve understanding of epidemiology in seed systems, taking into account socioeconomic components.

Ideally, seed systems give farmers access to affordable diseasefree, disease-resistant, high-quality seed. In practice, most farmers in low-income countries (e.g., $98 \%$ of potato farmers in the Andes)

†Corresponding authors. K. A. Garrett: E-mail: karengarrett@ufl.edu and C. E. Buddenhagen: E-mail: cbuddenhagen@ufl.edu

C. E. Buddenhagen and J. F. Hernandez Nopsa made equivalent contributions to this article.

*The $\boldsymbol{e}$-Xtra logo stands for "electronic extra" and indicates that one supplementary file is published online.

Copyright (C) 2017 The Author(s). This is an open access article distributed under the CC BY 4.0 International license. save seed from the previous season for replanting (Devaux et al. 2014; Jaffee et al. 1992). Farm yields using saved seed are often poor compared with using "improved seed". This higher quality seed is produced using enhanced on-farm management of pests and diseases, disease resistance deployment and by setting and meeting seed certification standards. The recommended suite of practices for seed system enhancement has been proposed as an "integrated seed health strategy" (Thomas-Sharma et al. 2016, 2017). Scientists contribute to seed systems by developing more disease-resistant varieties with other positive traits for dissemination through the system. Understanding seed systems can help scientists develop recommendations for system improvement based on linked epidemiological patterns and socioeconomic factors across a range of scales.

The risk of seedborne disease is particularly important in vegetatively propagated crops such as potato, sweetpotato, yam, cassava, banana, and many other fruits, compared with "botanical seed" or "true seed". "Seed degeneration" is the reduction in yield or quality caused by an accumulation of pathogens and pests in planting material over successive cycles of vegetative propagation (Thomas-Sharma et al. 2016, 2017). Epidemiological models for vegetatively propagated crops must take into account the accumulation and spread of disease in planting materials (Thomas-Sharma et al. 2017). Although seed transaction networks are sometimes studied and characterized (Labeyrie et al. 2016; Poudel et al. 2015; Ricciardi 2015; Tadesse et al. 2016; Violon et al. 2016), there is great potential for developing new approaches to predict the spread of seedborne diseases and help target disease detection efforts, training, treatments, and other interventions (Andersen et al. 2017; Hernandez Nopsa et al. 2015; Pautasso et al. 2013; Tadesse et al. 2016). Here, we use epidemiological network analysis (Shaw and Pautasso 2014) of a seed potato network to understand and predict 
disease risk. We use a new type of scenario analysis for interpreting epidemic risk in seed systems that takes into account farmer information sources.

Efforts to improve seed systems often fail to improve the disease status of crops (Devaux et al. 2010, 2014; Hirpa et al. 2010; Jaffee et al. 1992; Kromann et al. 2016; Panchi et al. 2012; Thiele et al. 2011; Thomas-Sharma et al. 2016). Understanding the structure and function of formal (state-regulated) (Sperling et al. 2013; Thiele 1999), informal, and mixed-seed systems can support the development of more sustainable seed systems. Aspects that determine the degree of seed system utility, sustainability, and resilience include access to and availability of seed, seed quality, cultivar quality (e.g., adapted, disease resistant, and matching user preferences), affordability, and profitability (Sperling et al. 2013; RTB 2016). There are tradeoffs in connectivity for farmers, where high connectivity is good for getting access to new varieties and training but can increase the risk of being exposed to disease. Managing connectivity can help to increase system resilience (Biggs et al. 2012).

Seed system resilience is tested when there are significant stressors or crises, be they environmental (Violon et al. 2016), biotic (e.g., pathogen or pest outbreaks), or socioeconomic (McGuire and Sperling 2013). Though broad categories of threats are predictable, some events may be viewed as crises because they are spatially varied, temporally unpredictable, and may have multiple distinct drivers (e.g., pathogen, drought, conflict, and economic crises). In high-income countries, regulation plays a substantial part in keeping a profit-driven sector functioning in everyone's interests (Frost et al. 2013). However, formal seed systems can be "static and bureaucratic" (Lybbert and Sumner 2012) where seed certification standards are often unachievable with reasonably available resources. Often, resource-poor farmers are priced out of the formal system, or government-subsidized systems can be unreliable. Sometimes improved varieties require inputs that are out of reach for resource-poor farmers, or disease pressure is enough to require many inputs. These are common explanations for the persistence of lower-performing informal seed systems even after interventions that seek to improve them. Governmental and aid-based interventions often emphasize provision of single threshold certified seed for both traditional and improved varieties to as many resource-poor farmers as possible (Tadesse et al. 2016). Despite repeated failures, development agencies continue to orient their interventions toward the development of regulated (McGuire and Sperling 2008, 2013) demand-driven systems that support a for-profit model of seed supply, believing them to be more sustainable and resilient (McGuire and Sperling 2013; Sperling et al. 2013). Often, after project funds are discontinued, the subsidized formal seed systems revert to largely informal ones with poor access to improved seed. A common belief is that this lack of resilience relates to a lack of diversity in terms of crops and cultivars, or supply channels (McGuire and Sperling 2013). It would seem that farmer decision making is poorly understood. Changes to on-farm disease management practices might provide comparable yield benefits for some scenarios (Thomas-Sharma et al., 2017) while being more sustainable within persistently informal systems.

A frontier for plant epidemiology is to better incorporate and model pathogen spread while taking into account actual human decision-making about disease management (McRoberts et al. 2011). Seed system development efforts often attempt to foster equitable access by stakeholders to services (Ricciardi 2015). For example, they often seek to address access differences that may be associated with gender, ethnicity, class or other individual traits. Epidemiological network analyses can help to identify systemic vulnerabilities that affect some groups' access to quality planting materials, IPM information, and the market for products (Tadesse et al. 2016). Clearly, short- and long-term planning by government agricultural agencies, farmers, and aid agencies could help to meet the variety of seed supply challenges. Stakeholders, especially governments and nongovernmental agencies, need to be flexible to strike a good balance between sustaining and transforming systems. Trade-offs are likely, with interventions under one scenario or set of stressors potentially being counterindicated in another scenario or for some stakeholders.

The risk that pathogens can move through a seed system network is a key component of disease risk, along with other risk factors such as potential transmission by vectors or wind dispersal. Detection of pathogens in a seed network in a timely manner can allow for mitigation measures to be implemented. Hub nodes (nodes with many links) and bridge nodes (nodes that connect distinct regions of a network) will tend to have important roles in the risk of pathogen spread and in sampling and mitigation (Hernandez Nopsa et al. 2015). However, nodes on the periphery of a network could be the entry point for an invasion of that network (Xing et al. 2017). Although the importance of hub and bridge nodes is intuitive, key roles of other nodes may be revealed in more detailed analyses of likely patterns of pathogen spread. Strategies for dissemination of resistant varieties may need to change depending on network properties. In addition, the spread of endemic pathogens such as Rhizoctonia spp. or the potential arrival of emerging diseases from distant locations (e.g., Dickeya spp.) (Czajkowski et al. 2011, 2015; Toth et al. 2011) can be modeled and mitigation strategies tested using a multilayer network analysis (Garrett 2012, 2017).

Exponential random graph models (ERGM) can be used to characterize networks in terms of the likelihood that links exist between different types of nodes (Handcock et al. 2008). ERGM have been used extensively in social sciences and can be used to identify actors that have key roles in epidemics or experience particular risk. In plant disease epidemiology, ERGM have the potential to contribute to analyses of human effects on and responses to disease risk and of interactions among different types of pathogens, vectors, and environments (Welch et al. 2011).

The study presented here addresses the challenge of understanding the strengths and vulnerabilities of multilayer seed system networks, considering both the network of seed transactions and the network of communication about IPM. We introduce a new type of scenario analysis for studying potential epidemics in seed transaction networks and the role that particular network nodes play in sampling and mitigation of epidemics. This analysis focuses on the component of disease risk due to the structure of seed networks. To this end, our objectives were to (i) characterize cultivar dispersal through a potato seed system in Ecuador, (ii) determine whether gender is associated with different types of network transactions or access to information, (iii) model the potential spread of a seedborne pathogen through the seed system to assess the risk level at each node to evaluate their utility as control points for pathogen mitigation measures, and (iv) characterize how the seed system transaction network might adapt to a scenario where the Consorcio de Productores de Papa (CONPAPA) management team and consortium no longer plays an organizing role and existing seed multipliers must compensate for its absence.

\section{MATERIALS AND METHODS}

Study system context: Seed degeneration. Viruses such as Potato virus Y (PVY), Potato virus X (PVX), and Potato leafroll virus (PLRV), are major causes of seed degeneration in many parts of the world (Frost et al. 2013; Salazar 1996). Additionally, depending on the geographic region, fungi, bacteria, nematodes, phytoplasmas, and insects can also play important roles in potato seed degeneration (Thomas-Sharma et al. 2016). In high-elevation potato production regions of Ecuador, Rhizoctonia solani is a major cause of seed degeneration (Fankhauser 2000) whereas, in many other tropical and subtropical countries, Ralstonia solanacearum is a major concern (Mwangi et al. 2008). Adding to this complex etiology, the rate of degeneration is also highly variable across 
geographical regions. Factors such as host physiology, vector dynamics, environmental variability, and the choice and success of management strategies can affect the rate of degeneration (ThomasSharma et al. 2016, 2017). In high-elevation regions, for example, lower temperatures can limit vector activity and pathogen multiplication while also influencing host physiology that limits pathogen transmission into daughter tubers (Bertschinger 1992; Navarrete et al.2017). In at least one case, the presence of Potato yellow vein virus (PYVV) was associated with small yield improvements, possibly via a competitive interaction with other viruses (Navarrete et al. 2017). In the Andes, evidence suggests that virus transmission to daughter tubers is usually incomplete, with between 30 and $75 \%$ of tubers being infected (Bertschinger et al. 2017). Similarly, the application of management strategies such as resistant cultivars, certified seed material, and other on-farm management strategies, individually or collectively, can affect the spread of disease epidemics in a region (Thomas-Sharma et al. 2017). A better understanding of these interrelated factors could contribute to the design of an integrated seed health strategy for a specific geographic region (Thomas-Sharma et al. 2016).

Study system: The CONPAPA potato seed system in Tungurahua, Ecuador. There are approximately 50,000 ha of potato production in Ecuador, with $97 \%$ of this area located in the Andes and $87 \%$ of farms being less than 10 ha in size (Devaux et al. 2010). It is possible to produce tubers all year, which has created a market that expects fresh potato for consumption year round (Devaux et al. 2010). Seed tubers from a farmer's previous season are typically planted in the next. This makes the potato crop subject to seed degeneration and yield losses (Thomas-Sharma et al. 2016). The national agricultural research institute (Instituto Nacional de Investigaciones Agropecuarias [INIAP]) is the only agency in Ecuador registered to produce formal basic seed potato. However, according to a 2012 estimate, less than $3 \%$ of the seed potato used in Ecuador is from the formal system (Thomas-Sharma et al. 2016). Two preferred cultivars for farmers in the Ecuadorian Andes are INIAP 'Fripapa' and 'Superchola'. However, farmers also grow many other cultivars such as INIAP 'Gabriela', INIAP 'Catalina', and 'Diacol-Capiro'. Seed is produced by INIAP from prebasic seed, which are minitubers produced from in vitro plants. Basic seed, the next generation, is multiplied in the field by INIAP or associated farmers. The next three generations of seed include three seed categories-registered seed (semilla calidad I), certified seed (semilla calidad II), and selected seed (semilla calidad III) — and are produced in the field by seed producers. Trained seed producers form a part of CONPAPA and produce seed for member farmers. The yield increase associated with each of these three categories has been reported to be 17,11 , and $6 \%$, respectively, compared with the seed produced by the farmers in the informal system (Devaux et al. 2010), although these estimates are low compared with the potential $(30 \%)$ yield increases reported globally from the use of quality seed potato (Thomas-Sharma et al. 2016). Established in 2006, CONPAPA has a membership of approximately 300 farmers in central Ecuador (principally in Tungurahua, Chimborazo, and Bolívar Provinces). This organization is the current realization of various aid and governmental efforts to improve livelihoods for small-scale potato farmers (Kromann et al. 2016). It aims to support small-scale farmer associations that produce seed potato and potato for consumption (ware potato) through training and provision of quality-assessed seed, and by processing and marketing produce (Fig. 1). It cleans and processes produce (e.g., for chips and fresh potato) in regional processing facilities and sells ware potato crops on behalf of members. Annual mean production yield of ware potato in CONPAPA (Tungurahua) ranges between 15 and 20 metric tons ( $t$ )/ha, with production levels being influenced by management, variety, time of year, and the number of generations since the seed was sourced from basic seed. Average production reported by CONPAPA is higher than the $9.5 \mathrm{t} / \mathrm{ha}$ that has been reported for Ecuador as a whole (Devaux et al. 2010). CONPAPA in Tungurahua reported (www.conpapa.org) that it supplies more than $25 \mathrm{t}$ of potato for consumption per week to meet market demand ( $0.3 \%$ of Ecuador's total production) (Devaux et al. 2010). Importantly, CONPAPA has trained seed multipliers who provide seed for redistribution to member farmers.

Survey methods. This study focuses on 48 farmers who are members of CONPAPA in Tungurahua Province. This is $66 \%$ of the 72 heads of households registered as members in this region (F. Montesdeoca, personal communication). However, the 48 farmers in this study represent a census of all the active farmers at the time of this study. We conceptualize the farmers' reported transactions as a sample of their typical types of transactions across seasons. Farmer network sizes and farmer activity can change as farmers opportunistically pursue a variety of alternative livelihoods from year to year (e.g., construction or service jobs) in response to changing conditions (in good and bad years) (Violon et al. 2016). A survey was completed by scientists via on-farm voluntary interviews of 48 farmers in the CONPAPA district of Tungurahua over 3 weeks in November and December 2015. In addition to demographic information, the survey documented the seed sources, cultivars planted, volume bought, and price paid for the last three planting periods, as reported by farmers. Farmers were also asked to report (i) the sale or use of potato for food, including destination, cultivar, volume, and price received; (ii) the principal pests and diseases they observed; and (iii) their sources of advice regarding IPM and the confidence they had in that advice. In some cases, there was missing data related to volume or price information. The results of this survey are available at http://dx.doi.org/10.21223/ $\mathrm{P} 3 / \mathrm{XKHUTL}$ and the data specifically used in these analyses are included in Supplementary File S1.

Data analysis and modeling. Networks of seed and ware potato transactions between the farmers and other stakeholders were analyzed using the igraph and statnet packages (Csárdi and Nepusz 2006; Handcock et al. 2008) in the R programming environment (R Core Team 2017). Selected R scripts and the resulting output are available through links at http://www.garrettlab.com/epid-seed/, along with an interactive interface for understanding the structure of epidemic risk in the CONPAPA system. The adjacency matrix we evaluated was based on reported sales, where a link indicates a directed transaction resulting in the movement of seed or ware

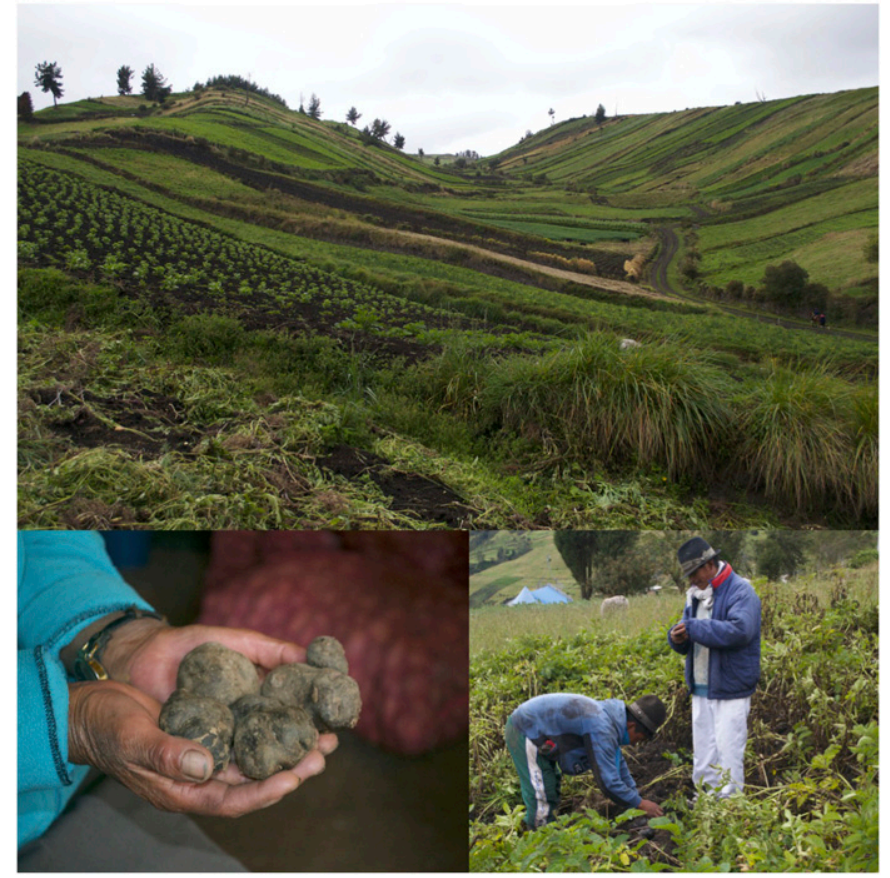

Fig. 1. Potato production by farmers in the CONPAPA seed system in Tungurahua Province, Ecuador (photos: J. F. Hernandez Nopsa). 
potato. For cases where farmers reported a transaction but did not give volume information, links were depicted in the network as dotted lines and given a minimum visible width. Missing price and volume data were not treated as zeroes but were omitted from the calculation of means and percentages. Missing volume and price data are reported in the results. Transaction counts, volumes and prices were compared with respect to potato cultivar and farmer gender, based on percentages, means, and two-sided Wilcoxon tests (using the wilcox.text function in R). Although the farmers sampled represent a complete census of the CONPAPA farmers, we treat their reported information as a sample of reported transactions across years. We evaluated the effect of node type (farmer or institution) on the likelihood that a link exists in the potato transaction network using the ergm function in the statnet package in $\mathrm{R}$ (Handcock et al. 2008).

A second adjacency matrix describing communication was evaluated, based on the information sources that farmers reported related to disease and pest management. Links in this matrix indicate the reported flow of information. Based on the structure of this network, the information access of each node (farmer or other information source) was evaluated in two ways. "Information quantity" was defined as the number of information sources a node accesses, or the in-degree for a node. "Information quality" was defined as the maximum level of trust reported for any of a node's sources of information.

The frequency with which common pests and diseases were reported by farmers, including diseases responsible for seed degeneration, is reported overall and by gender (where gender differences were tested using $\chi^{2}$ tests).

Rating the importance of nodes for sampling efforts. Optimal management of potential invasive pathogens in a seed system depends on identifying the most important geographical nodes for sampling to detect disease (in both the field and harvested tubers). Sampling some nodes will tend to result in rapid detection of the pathogen whereas sampling other nodes will likely only detect the pathogen after it has already spread widely in the network. In a scenario analysis, pathogen spread was simulated across

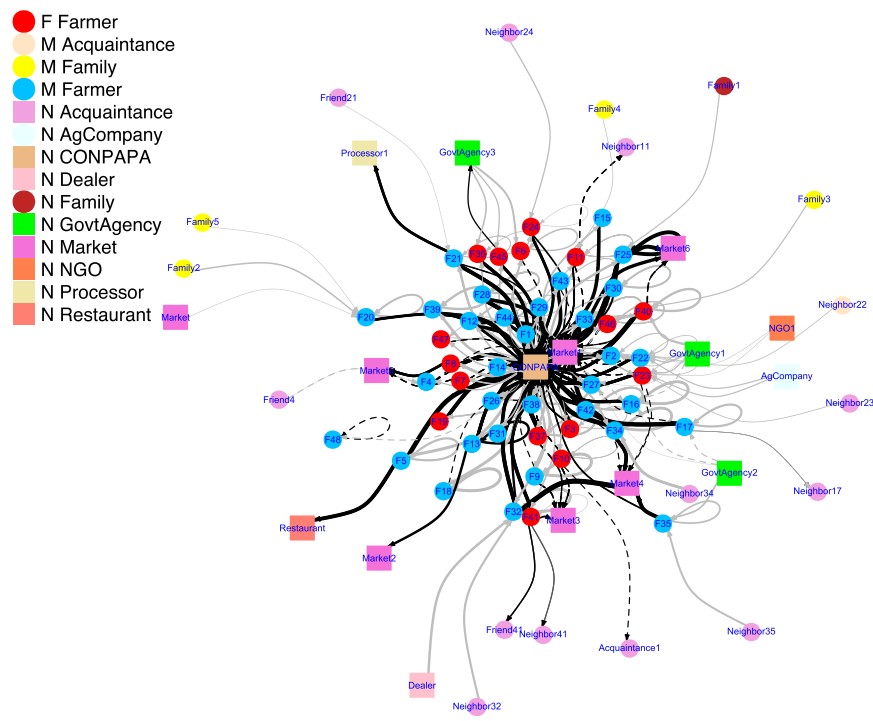

Fig. 2. Seed system transaction network, in which nodes represent 48 farmers associated with CONPAPA in Tungurahua, Ecuador, along with other institutions and individuals linked with them. Links indicate reported potato movement, and are weighted by the volume (proportional to line thickness) of seed and ware potato bought, sold, used or traded by farmers. Data are from the three most recent seasons in November 2015. Black lines indicate seed and gray lines represent potato for food consumption. Self-loops represent seed produced on-farm. Dotted lines represent transactions where volumes were not reported. The Fruchterman Reingold layout was used for generating the network representation. $\mathrm{F}=$ female, $\mathrm{M}=$ male, and $\mathrm{N}=$ no gender or unknown. the seed and ware potato distribution network, where the network was based on reports aggregated across the last three plantings and actual or anticipated harvest dates ranged from May 2014 to May 2016. In the simplest version of the analysis, each node was considered equally likely to be the point of initial introduction of a pathogen into the seed system network. Another version of the analysis drew on the structure of the communication network. In this case, the probability that a pathogen would be introduced into the network by a given farmer was weighted by a function of that farmer's level of information quantity or quality (defined above), as a proxy for the node's ability to respond effectively. The idea is that a well-informed farmer (with high information quantity or quality) will be less likely to be a point of disease introduction into the network, and will be more prepared to keep a new pathogen from becoming established.

Information quantity and quality were converted to weights that reflect whether a node has adequate information to manage an invasive pathogen. For information quantity, we considered the probability $\left(p_{1}\right)$ that the necessary information is not obtained from a given source node. We evaluated the probability that the information was not received from any of the potential sources, as $p_{1}$ to the power of the node in-degree, for $p_{1}=0.1,0.3,0.5$, and 0.9 . Differences were most obvious for $p_{1}=0.1$ and 0.9 and are illustrated in Figure 4. For nodes that had no reports about information quantity, in-degree was set to 3 for individuals, 10 for institutions, and 0 for markets. Information quality was sampled as a reported level of trust ( $y$ ) for each information source, on a scale of 0 to 5 . Information quality was transformed as $1-\max (y) / 5$. Because $\max (y)$ was usually 5 , we also consider scenarios without "certain successful management" by multiplying $1-\max (y) / 5$ by $0.1,0.5$, and 0.9. For nodes for which we had no reports about information quality, $\max (y) / 5$ was taken as the reported farmer average (0.9) for nodes representing other individuals, as 1 for nodes representing institutions, and as 0 for markets.

The simulation of epidemic spread generates an estimate of the number of nodes infected before the disease will be detected at each potential sampling node, given that each potential starting node has a weighted probability of being the initial source based on information quantity or quality. The output allows us to estimate relative value of a node for monitoring in terms of the number of nodes that would be infected if only the node in question were monitored.

Scenario analysis where the CONPAPA management team does not supply seed. The CONPAPA management team is clearly central to this seed system, a key "cutpoint" or node whose removal creates multiple disconnected components in the network. We explored how resilient the seed system might be if the CONPAPA management team were removed. How would other nodes need to compensate for its absence? We compared the scenario where the CONPAPA management team provides seed to farmers and multipliers with a scenario where it does not have a role in seed provision. For this alternative scenario, we evaluated the reported volumes for seed transactions over three plantings. Then, where the CONPAPA management team provided basic seed to multipliers, we replaced these transactions with INIAP, the government agency that provides basic seed to CONPAPA. Finally, where farmers sourced their seed from the CONPAPA management team, they instead sourced their seed from the geographically nearest multiplier (farmers 7, 27, 34, and 46). Thus, the alternative scenario maintains the same transaction volumes that were reported but removes the CONPAPA management team as the go-between, replacing it with the most plausible alternative. We evaluated the structure of this new network.

\section{RESULTS}

Seed system: Overview. The seed system network depicted in this study is sparse, has highly heterogeneous in-degree, with a degree of clustering and higher-level cycles, while links are directed, 
weighted, and dynamic. It is centered around the CONPAPA management team in Tungurahua, which provides and receives seed and ware potato from member farmers (Fig. 2). In total, 1,157 quintals (45.36-kg bags), or $52 \mathrm{t}$, of seed was reported as used by farmers in the most recent planting, where CONPAPA provided $47 \%$ of the seed, $36 \%$ was farmers' saved seed, and the remaining $16 \%$ came from other sources. CONPAPA was reported as receiving only $7 \mathrm{t}$ of seed from trained male seed multipliers. Only two women (farmers 7 and 46) reported providing seed (Puca, Fripapa, and Superchola) to CONPAPA during this interval, although farmers 7, 8, $10,19,36,40,46$, and 47 are women trained to be seed multipliers. Of the 48 farmers that reported buying or selling potato or seed, $16(33 \%)$ were women. Farmers reported a total of 503.9 t of potato being sold, with CONPAPA buying $414.7 \mathrm{t}$ (82\%) of potato (where $28 \%$ of this was from women). Farmers reported selling $85.3 \mathrm{t}$ directly to local markets, and one farmer reported selling $3.2 \mathrm{t}$ directly to a restaurant. It is important to note that 262 transactions were reported in the most recent season but interviewees did not provide volume for 71 transactions or price information for 58 transactions (including selfsupplied seed transactions). On a per-transaction basis, there was a difference between the volume of ware potato sold by women (median $=5$ quintals) and men (median $=40$ quintals) (Wilcoxon test [two-sided], $W=2,594, P$ value $=1.8 \mathrm{e}-08$ ). In the ERGM analysis, node type had an effect on the likelihood that reported links exist in the seed and ware potato transaction network $(P<0.0001)$. Farmers were much more likely to report transaction links with institutions than with other farmers, suggesting that the system is "formalized" to a great extent with respect to off-farm seed acquisition. There was also evidence for a difference in per-transaction volume for seed tubers between women and men, with medians of 3 and 5 quintals, respectively (Wilcoxon test [two-sided], $W=5,142.5, P$ value $=$ $0.0002)$. There was no evidence for a difference in per-transaction prices for ware potato for women and men, with medians of U.S.\$15 per quintal being received by both genders (Wilcoxon test [twosided], $W=2,513, P$ value $=0.9$ ). Prices were infrequently reported. Unreported here is the movement of prebasic seed to CONPAPA from INIAP. CONPAPA in Tungurahua may also receive seed from CONPAPA multipliers outside of the region. Farmers reported replacing seed every three to four seasons, indicating that purchased seed is grown alongside seed saved from previous plantings.

Most transactions were with CONPAPA and the market in the nearby town of Ambato. More than $88 \%$ of the transactions were between actors that were $>10 \mathrm{~km}$ apart. There were no CONPAPA member farmer-to-farmer transactions. Only $7 \%(n=40)$ transactions

TABLE 1. Number of transactions and number of farmers using each cultivar for the current season, with percentages, as reported in November 2015

\begin{tabular}{|c|c|c|c|c|c|c|c|}
\hline \multirow[b]{2}{*}{ Cultivar } & \multirow[b]{2}{*}{ Total $^{\mathrm{a}}$} & \multicolumn{2}{|c|}{$\begin{array}{c}\text { Seed } \\
\text { potato }\end{array}$} & \multicolumn{2}{|c|}{$\begin{array}{l}\text { Ware } \\
\text { potato }\end{array}$} & \multicolumn{2}{|c|}{$\begin{array}{l}\text { Farmers } \\
\text { using the } \\
\text { cultivar }\end{array}$} \\
\hline & & $n$ & $\%$ & $n$ & $\%$ & $n$ & $\%$ \\
\hline Superchola & 90 & 40 & 32 & 50 & 36 & 31 & 33 \\
\hline Fripapa & 56 & 28 & 22 & 28 & 20 & 16 & 17 \\
\hline Puca-shungo & 27 & 13 & 10 & 14 & 10 & 12 & 13 \\
\hline Yana-shungo & 17 & 9 & 7 & 8 & 6 & 8 & 8 \\
\hline Unica & 16 & 7 & 6 & 9 & 7 & 6 & 6 \\
\hline Carolina & 13 & 6 & 5 & 7 & 5 & 4 & 4 \\
\hline Victoria & 10 & 4 & 3 & 6 & 4 & 4 & 4 \\
\hline Gabriela & 8 & 3 & 2 & 5 & 4 & 3 & 3 \\
\hline Chaucha & 7 & 4 & 3 & 3 & 2 & 3 & 3 \\
\hline Carrizo & 6 & 3 & 2 & 3 & 2 & 2 & 2 \\
\hline Suprema & 4 & 2 & 2 & 2 & 1 & 2 & 2 \\
\hline Americana & 2 & 1 & 1 & 1 & 1 & 1 & 1 \\
\hline Natividad & 2 & 2 & 2 & 0 & 0 & 1 & 1 \\
\hline Norteña & 2 & 2 & 2 & 0 & 0 & 1 & 1 \\
\hline Tulca & 2 & 1 & 1 & 1 & 1 & 1 & 1 \\
\hline
\end{tabular}

a Total transactions. were with neighbors and $1 \%$ were with family members (for which there was no geographic location data).

Seed system: Analysis by variety. Overall, although farmers planted, on average, two cultivars, the median use was just one. In other words, about half of the farmers reported planting a single cultivar while the other half planted two to five different cultivars. Ranking the use of cultivars by the numbers of farmers using them matches almost exactly the ranking by number of transactions per cultivar (Table 1), which suggests that the high number of transactions for the main cultivars is driven by their overall popularity. The three most commonly planted cultivars, according to these criteria, were Superchola (33\% of farmers planted it, its product transactions represent $36 \%$ of all transactions, and its seed transactions $32 \%)$, Fripapa $(17,20$, and $22 \%)$, and Puca $(13,10$, $10 \%$ ), in respective order of ranking.

A second comparison of the total volume of transactions by cultivar shows that the three most frequently exchanged cultivars were also the ones with the greatest transacted volumes (Table 2).

TABLE 2. Volume of seed in quintals (where 1 quintal $=45.63 \mathrm{~kg}$ ) and product exchanged, with percentages

\begin{tabular}{|c|c|c|c|c|c|c|}
\hline \multirow[b]{3}{*}{ Cultivar } & \multicolumn{4}{|c|}{ Total volume } & \multicolumn{2}{|c|}{$\begin{array}{l}\text { Volume per } \\
\text { transaction }\end{array}$} \\
\hline & \multicolumn{2}{|c|}{ Product } & \multicolumn{2}{|c|}{ Seed } & \multirow{2}{*}{$\frac{\text { Product }}{n}$} & \multirow{2}{*}{$\frac{\text { Seed }}{n}$} \\
\hline & $n$ & $\%$ & $n$ & $\%$ & & \\
\hline Superchola & 4,580 & 40 & 425 & 35 & 143 & 11 \\
\hline Fripapa & 2,405 & 21 & 323 & 26 & 172 & 15 \\
\hline Puca-shungo & 999 & 9 & 80 & 7 & 111 & 7 \\
\hline Carrizo & 960 & 8 & 66 & 5 & 480 & 22 \\
\hline Victoria & 760 & 7 & 48 & 4 & 190 & 12 \\
\hline Unica & 600 & 5 & 116 & 9 & 200 & 19 \\
\hline Carolina & 470 & 4 & 79 & 6 & 118 & 13 \\
\hline Yana-shungo & 350 & 3 & 43 & 3 & 58 & 5 \\
\hline Gabriela & 90 & 1 & 6 & 0 & 45 & 3 \\
\hline Chaucha & 80 & 1 & 16 & 1 & 27 & 5 \\
\hline Suprema & 15 & 0 & 21 & 2 & 15 & 11 \\
\hline Americana & 0 & 0 & 1 & 0 & $\ldots$ & 1 \\
\hline Tulca & 0 & 0 & 0 & 0 & $\ldots$ & $\ldots$ \\
\hline Natividad & $\ldots$ & 0 & 90 & 7 & $\ldots$ & 45 \\
\hline Norteña & $\ldots$ & 0 & 0 & 0 & $\ldots$ & $\ldots$ \\
\hline
\end{tabular}

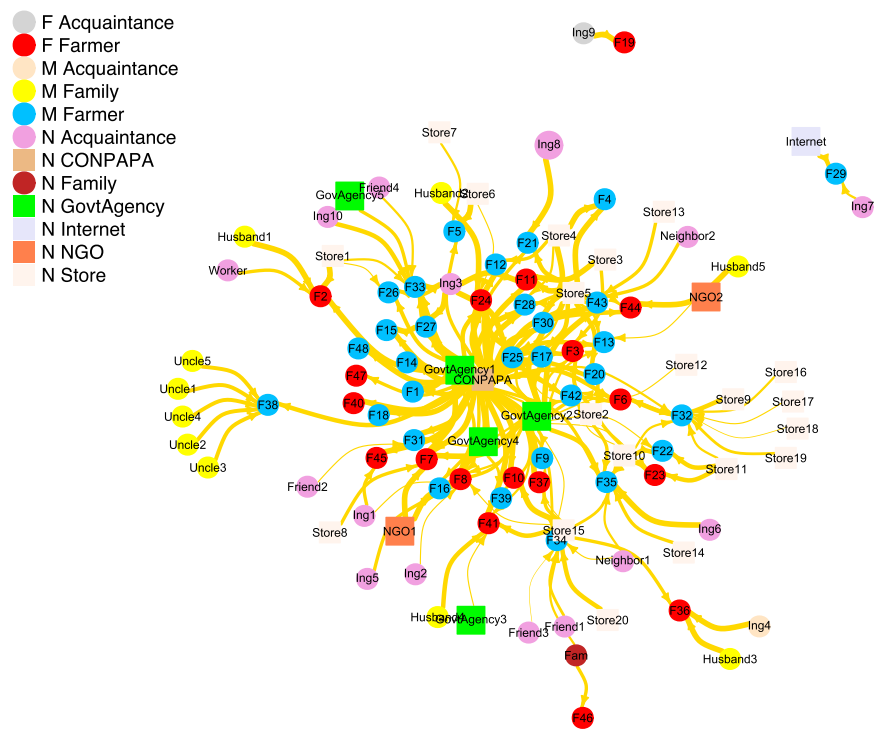

Fig. 3. Network depicting farmer-reported information sources for integrated pest and disease management. Link thickness is proportional to the reported level of trust that the farmer has in that source of information. The Fruchterman Reingold layout was used for generating the network representation. $\mathrm{F}=$ female, $\mathrm{M}=$ male, and $\mathrm{N}=$ no gender or unknown. 
Indeed, Superchola's transacted volume represented $40 \%$ of all volume transacted in terms of ware potato and $35 \%$ in terms of seed. Fripapa's seed volume transacted was higher than the ware potato volume transacted at 26 versus $21 \%$. Finally, the volume of Puca represented $9 \%$ of ware potato and $7 \%$ of seed. Interestingly, two varieties that were not reported by the majority of farmers- 'Carrizo' and 'Victoria' - represented 8 and 7\%, respectively, in terms of volume transacted, almost as much as Puca. This occurred because a few farmers provided large volumes of product to a few non-CONPAPA buyers. Finally, the percent seed volume transacted for 'Unica' was larger than for Puca (9\%) and 'Natividad' was the same as Puca (7\%).

IPM information. Farmers largely reported obtaining information about integrated pest and disease management (IPM) from the CONPAPA management team (mean in-degree for information received by farmers was 3.5 overall) (Fig. 3). There was not evidence for a difference (Wilcoxon test, $W=236, P$ value $=$ 0.4668 ) between male (3.7) and female (3.2) in-degree with respect to number of information sources reported. Importantly, farmers frequently reported receiving information from agrichemical stores (Fig. 3, green squares). Family members also provided important sources of information about IPM (Fig. 3). A quarter of the women reported their husband as a source of information for IPM but no men reported that their wife was a source of IPM information. Farmer-assessed trust levels ranged between zero and five. There was some evidence for a difference in median trust levels reported by men and women (3 compared with 5, respectively) for CONPAPA (Wilcoxon test, $W=5364, P$ value $=0.02$ ). though the pattern was less obvious when trust levels reported by women with respect to IPM information from their husbands were removed (median of 3.5 and 4 for men and women, respectively; Wilcoxon test, $W=$ 4825.5, $P$ value $=0.06$ ). The main sources of information were CONPAPA and agrochemical stores, where the median trust level reported by farmers for all stores was 3, compared with 5 for CONPAPA (Wilcoxon test, $W=457, P$ value $=2.2 \mathrm{E}-6$ ) Only one farmer reported the internet as an important source of information about management.

The most frequently reported diseases and pests were potato late blight, Andean potato weevil, and potato black leg. Despite prompting, viruses were reported by only $1 \%$ of farmers (Table 3 ). Slugs and leaf miners were more frequently reported as a problem by women than men, though rates were low (Table 3 ).

Effective sampling for disease in the system. Under the scenarios we evaluated (Fig. 4A to C), the CONPAPA management team is the most effective place to monitor in order to detect a disease before it has spread far. This reflects its central role in the network. Similarly, several stakeholders and farmers at the periphery of the seed and potato network tended to be poor locations for detecting potential disease in every simulation. This is because they only provided seed rather than receiving seed or product (Fig. 4A to $\mathrm{C}$, dark purple) in this network, or had low in-degree (Fig. 4A to $\mathrm{C}$, blue or light purple). Weighting risk of establishment based on the information quantity for IPM (Fig. 4B) causes some nodes of intermediate importance to become more important for monitoring, particularly where we assume that the first few information sources a node has access to have the greatest impact on management $\left(p_{1}=0.1\right)$. The results for the scenario with risk weighted as a function of the quality (trust) of information were very similar to the case where all nodes were weighted equally. In all cases, the market in Ambato, the largest town in the region, is also a good place to monitor, though we assume that, even with good information available about IPM, this would do little to change disease risk there. This particular market had the highest reported in-degree of any of the five markets. An important caveat is that, clearly, not all diseases can be mitigated effectively by IPM; this assumes that an IPM intervention is available to farmers so that they can reduce the probability of disease establishment.

Scenario analysis where the CONPAPA management team does not supply seed. We compared two scenarios: the current one in which the CONPAPA management team provides seed to farmers and multipliers and multipliers sell their seed to CONPAPA (Fig. 5A), and the other where the CONPAPA management team does not have a role in seed provision (Fig. 5B). In the second scenario farmers access to multipliers is based on proximity, and as such multipliers do not have equal access to all the seed-buying farmers in the network (Fig. 5B). CONPAPA's role as distributor and organizer of seed distribution (Fig. 5A) may result in all farmers having access to seed from any of the multipliers.

\section{DISCUSSION}

In this analysis, we demonstrate an approach for identifying priorities for monitoring plant health in seed systems. In this relatively small and centralized seed system, disease monitoring at CONPAPA processing facilities is obviously a high priority for detection of incipient disease because it receives high quantities of ware potato (it has high in-degree) and is the source of most of the improved seed (it has high out-degree). Monitoring at the market in Ambato (Figs. 2, 4, and 5, Market1) could also be relatively effective. Second, the analysis identifies other nodes in the network that can play a role in sampling and mitigation (Fig. 4), offering a method to rank and prioritize among these nodes for sampling in the field and postharvest. Mitigation measures during a disease outbreak, such as dissemination of new resistant cultivars, training, or treatment of fields, might also prioritize these nodes in the network. Network models provide a window into the epidemiology of plant diseases and strategies for efficient sampling for plant epidemic surveillance and other mitigation efforts (Chadès et al. 2011; Harwood

TABLE 3. Pests and diseases reported by farmers in Tungurahua, Ecuador, in order by the frequency of reports ${ }^{\mathrm{a}}$

\begin{tabular}{|c|c|c|c|c|}
\hline Pathogen (disease or pest) & Causing degeneration & Women reporting & Men reporting & Farmers $(\%)$ \\
\hline Phytophthora infestans (Late blight) & Yes & 15 & 30 & 94 \\
\hline Premnotrypes spp. (Andean potato weevil) & Yes & 10 & 26 & 75 \\
\hline Rhizoctonia solani (Potato black leg) & Yes & 7 & 16 & 48 \\
\hline Puccinia pittieriana (Common rust) & No & 6 & 12 & 38 \\
\hline Epitrix spp. (Potato flea beetles) & Yes & 3 & 9 & 25 \\
\hline \multicolumn{5}{|c|}{ Phtorimaea operculella, Symmestrichema tangolias, and Tecia solanivora } \\
\hline (Potato moths) & Yes & 4 & 4 & 17 \\
\hline Fusarium spp. (Fusarium rot) & Yes & 1 & 6 & 15 \\
\hline Liriomyza spp. (Leaf miner) ${ }^{\mathrm{b}}$ & Yes & 5 & 2 & 15 \\
\hline Slugs ${ }^{\mathrm{b}}$ & No & 4 & 0 & 8 \\
\hline Frankliniella tuberosi (Thrips) & Yes & 2 & 1 & 6 \\
\hline Nematodes & Yes & 1 & 1 & 4 \\
\hline Spongospora subterranean (Powdery scab) & Yes & 1 & 1 & 4 \\
\hline Septoria lycopersici (Annular leaf spot) & No & 0 & 1 & 2 \\
\hline Viruses & Yes & 1 & 0 & 2 \\
\hline White fly & Yes & 1 & 0 & 2 \\
\hline
\end{tabular}

a Pests and diseases known to cause seed degeneration are indicated.

b Gender differences are significant in a $\chi^{2}$ test $(\mathrm{a}=0.05, \mathrm{df}=1)$. 


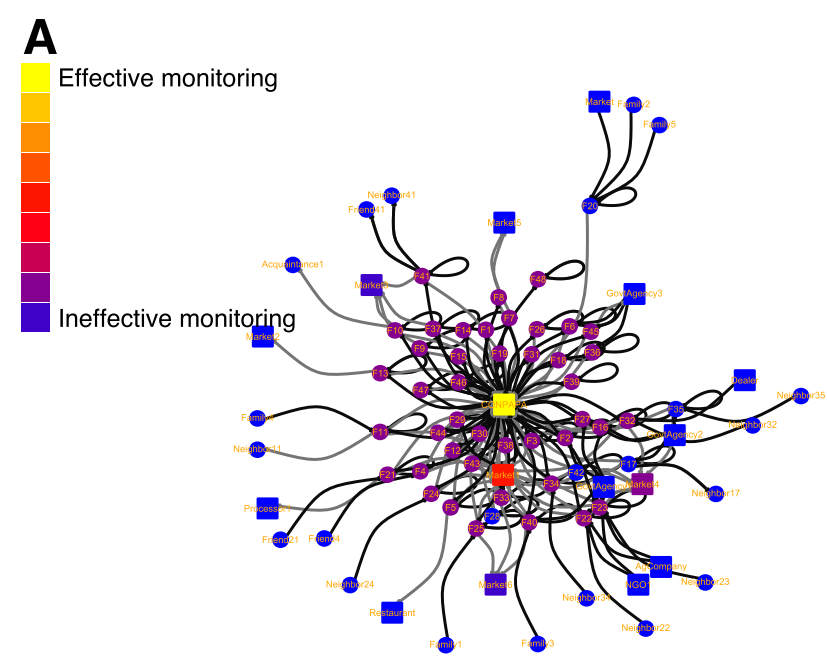

et al. 2009; Hernandez Nopsa et al. 2015; Sanatkar et al. 2015; Sutrave et al. 2012).

Information about the dispersal of particular cultivars through the seed network can provide insights into the likelihood of disease transmission, whether cultivars have resistance to a particular disease, or whether seed of a new cultivar is inadvertently a source of an introduced pathogen. In this simple system, the second most common variety (Fripapa) was only transacted by 16 of the farmers; thus, inadvertent spread of a disease in this variety would be far less consequential than in Superchola, which is cultivated by 31 farmers. Good information is available about cultivar susceptibility to Phytophthora infestans (Forbes 2012; Kromann et al. 2009) but studies of viral infection rates for cultivars used in Ecuador rarely consider more than a few varieties. Seedborne viral incidence, especially of PYVV, PVS, and PVX, was reported in

B

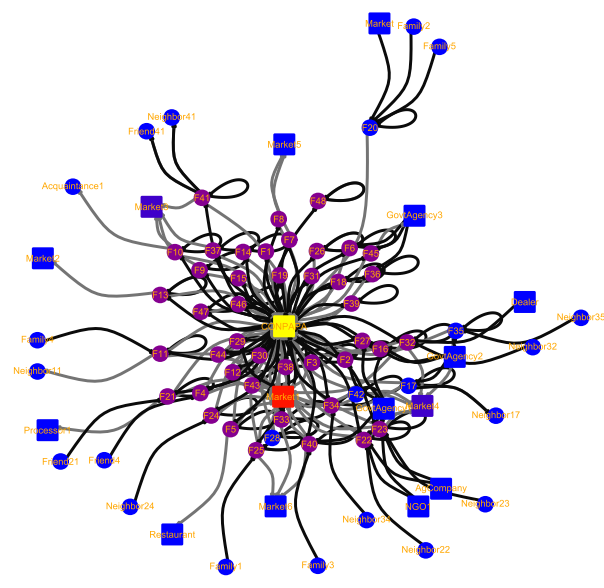

\section{C}

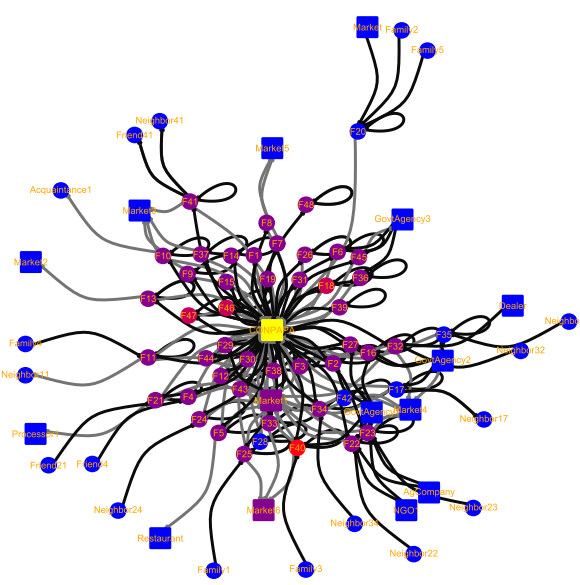

Fig. 4. The value of monitoring each node is evaluated in terms of the number of nodes (few = yellow and blue = many) that would become infected before the disease was detected at that node. This was based on simulated pathogen invasions, with initial infection starting at a random node and proceeding through the network defined by farmer transactions for seed (black) and ware potato (gray). This network represents the last three seasons reported in November 2015. Three scenarios were evaluated, where the probability or risk of the disease starting at a given farmer node is weighted differently. A, All farmers are equally likely to be an initial source of introduction of the pathogen into the network; $\mathbf{B}$, risk of being an initial source is proportional to 0.9 to the power of the number of sources (node in-degree, not including self-loops); and $\mathbf{C}$, risk of being an initial source is proportional to 0.1 to the power of the number of sources.
A

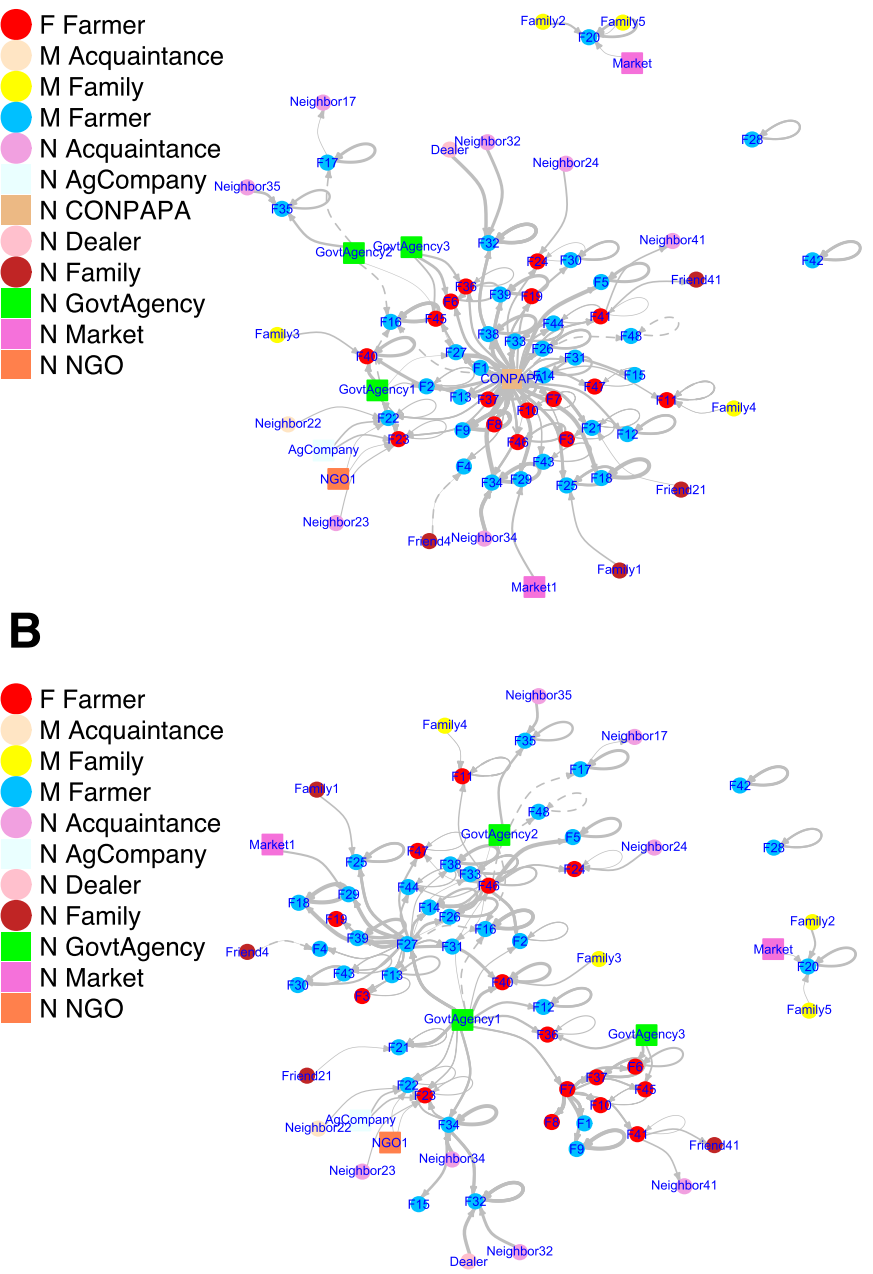

Fig. 5. Scenario analysis evaluating potential compensation in the system if the CONPAPA management team no longer played its central role. The figure compares $\mathbf{A}$, the current scenario, where it provides the majority of seed, with B, a hypothetical scenario where farmers get their seed from the nearest seed multiplier and the CONPAPA management team no longer plays a role. A, Seed transactions weighted by the volume based on reports from the last three plantings, including CONPAPA. B, Seed transactions (links) weighted by volume in a scenario where seed normally going from the CONPAPA management team to multipliers was replaced with seed from the government agency (Instituto Nacional de Investigaciones Agropecuarias). Seed that went from the CONPAPA management team to farmers is now provided by the nearest multiplier. Active multipliers are farmers 7, 27, 34, and 46. For A and $\mathrm{B}$, diameter $=4$ and 3 , density $=0.52$ and 0.52 , and mean of all the shortest paths $=2.1$ and 1.4, respectively. The Fruchterman Reingold layout was used for generating the network representation. $\mathrm{F}=$ female, $\mathrm{M}=$ male, and $\mathrm{N}=$ no gender or unknown. 
one study for some of the cultivars used by CONPAPA farmers (from lowest to highest incidence: Fripapa, Gabriela, 'Yana', Unica, 'Dolores', and 'Chaucha') but per-plant yield effects were negligible (Navarrete et al. 2017). High levels of PVY infection have been reported occasionally in Ecuador for Superchola and Fripapa, but viral incidence seems to depend on complex interactions between ecological conditions, on-farm management practices, vector biology, seed sources, and cultivar (Navarrete et al. 2017). Yana was reported as extremely resistant to PLRV and PVY whereas Unica was resistant to PVY but susceptible to PLRV (CIP 2009).

In Ecuador, seed degeneration, mostly attributable to viruses, can have important effects on yield (7 to $17 \%$ loss, or even gains, in the case of PYVV) but virus incidence is often low at high altitude, even if levels vary widely from site to site (P. Kromann, unpublished data) (Devaux et al. 2010; Navarrete et al. 2017; Panchi et al. 2012). It appears that the problem is still underappreciated and rarely recognized by farmers. For example, only one farmer reported viruses as a concern in this study. Yield losses of $\pm 30 \%$ from seed degeneration are common elsewhere in the world (Thomas-Sharma et al. 2016). In most Ecuadorian farms at high altitude, it is likely that the vector-based transmission rates are lower compared with other seed-tuber-producing areas worldwide.

We modeled the risk of disease entry into a seed network as a function of farmer information quality and quantity with respect to IPM. This is one approach to integrate the network for the spread of information about management with the biophysical network. A large share of farmers report that they draw on advice from agrochemical stores. Importantly, farmers do not report trusting them highly as a source of information compared with technical staff working for CONPAPA. Clearly, training these store owners about disease and pest management has the potential to be an effective measure to improve management outcomes for farmers inside and outside of the consortium. However, it is unclear whether training store owners would result in improved advice and the sale of appropriate pesticides, or whether potential economic conflicts of interest would influence the quality of their advice. There may be a financial incentive for small agrochemical store owners to simply recommend the application of the products that they have available for sale.

Women made up a third of the farmers and reported selling smaller volumes of ware potato on average. Clearly, they are making less money from potato farming than their male counterparts. There were limited differences in gender access in terms of the number of information sources or the trust they placed in those sources. A next step for understanding the role of gender in Andean seed systems would be to determine whether this is typical, or whether less formal seed system networks in the region reveal larger gender effects. It will also be useful to better understand the potential sources of bias in reporting of trust and other factors (e.g., how does gender influence whether people will tend to report higher or lower levels of trust?). An ERGM was used to evaluate the effect of node type on the probability of the existence of reported links. There is great potential for more extensive application of ERGM in plant disease epidemiology to test for treatment effects and to estimate and define network structures for applications such as scenario analysis. (For further exploration of this data set using ERGM, see links at http://www.garrettlab.com/epid-seed/.)

Better informed farmers may be more likely to implement effective management. When the value of the first couple of information sources is weighted heavily with diminishing returns for additional information sources, a wider range of risk types is observed among nodes. However, if we assumed that one source would provide good information and new sources incrementally more, the risk associated with most nodes was homogeneous. This highlights the importance of better understanding how farmers use information and the value of information that farmers receive from different sources. For some diseases, information about a simple IPM intervention could have a large impact whereas, in other cases, IPM interventions may be complicated to understand or implement, or information about effective intervention may be lacking. Future research could attempt to directly quantify the relationship between farmer knowledge and the risk of disease spread.

Most viruses are transmitted to daughter tubers and will be hitchhikers for each transaction of seed or potato. It is clear that some spread can always occur via the seed system. Network dynamics change from year to year; therefore, scenarios should consider temporal dynamics (e.g., the different effects of wet and dry years) (Violon et al. 2016). A more nuanced approach would also take into account different suites of viruses and the way their transmission rates from infected mother plants to daughter tubers vary depending on varietal and environmental conditions (Bertschinger et al. 2017). Thus, node (farmer) vulnerability to infection could also be modeled in terms of specific diseases and scenarios, and could account for varietal differences in resistance. In this system, most transactions were with CONPAPA, governmental institutions, or markets in nearby towns, mostly in Ambato, which was $>10 \mathrm{~km}$ from all the member farmers. Only $7 \%$ of transactions were with nearby neighbors (1\% with family), and were always of low volume. In many systems, the probability of transactions or epidemic spread between two cities or organizations follows a gravity model (i.e., it is a function of the distance and the product of the size of the two entities) (Jongejans et al. 2015).

A key point to consider for potato seed systems is virus transmission mechanisms. As a case in point, PVX and Andean potato mottle comovirus are transmitted by contact whereas others such as PVY, PLRV, and PYVV are vectored by aphids (Fankhauser 2000). Networks could include both spread through seed transactions and spread based on the spatial proximity of farm pairs (as a proxy for the probability of vector movement between a pair). In this study, farms were widely dispersed, with both potato and other crops being grown in the intervening areas. Inoculum sources could come from non-CONPAPA potato farmers or nonpotato host species. To realistically model seed infection by vectors would require detailed, disease-specific data sets that support accurate estimation of dispersal kernels, including the effects of infected volunteers and tuber waste from potato harvesting.

Implementation of fully formal seed systems in many lowincome countries is beyond the available resources of the agencies and farmers involved. Reaching the quality levels indicated in statutes may not be feasible. This means that most potato farmers in low-income countries operate wholly within informal seed systems. The CONPAPA seed system has been described as a mixed formal and informal system (Kromann et al. 2016). CONPAPA defines seed quality explicitly in three levels, with real quality-control measures in place. This means that farmers can buy improved seed of known quality with achievable quality levels for the stakeholders involved. The adoption of this alternative seed-quality-assessment scheme has been incorporated into formal Ecuadorian seed regulation (Kromann et al. 2016), thus formalizing the standards CONPAPA developed. This has been described as "providing flexibility" (FAO 2006) and is recommended as a means of achieving greater confidence by stakeholders and greater adoption of improved seed. More could be done to optimize thresholds for seedborne pathogens, balancing the cost of rejected seed lots against the benefit of reduced inoculum levels (Choudhury et al. 2017). Therefore, the CONPAPA seed system could be characterized as predominantly formal, with the quality-declared seed sources accounting for $47 \%$ of the seed in this study. In practice, the mean time between seed replenishment was reported to be approximately three to four seasons, though we also found that improved seed is often planted together with reused seed in any given year. This is a much higher rate of improved seed use than the 2 to $3 \%$ formal seed sources reported for Ecuador and Bolivia (Almekinders et al. 2007; Devaux et al. 2010). There are multiple farmer cooperatives that follow the CONPAPA model in central Ecuador and all are adding value. A local leader at Tungurahua has helped to achieve particularly high levels of cohesion and provide 
tangible benefits to the member farmers there. CONPAPA's cooperative model, combined with the seed-quality-assessment system, could help to overcome issues of access and household economic insecurity that impacted participation in formal seed systems elsewhere (Okello et al. 2016). This could have important consequences because potato is becoming increasingly important as a staple crop in areas where informal seed systems prevail (Devaux et al. 2014).

We evaluated the CONPAPA structure as a first step to support improved sampling, IPM, risk assessment for pathogen and pest movement, and farmer decision making. Identification of key control points that influence the success of seed systems (e.g., farmers, farms, and information sources) supports enhancement of the system (e.g., maximizing the distribution of new seed varieties using fewer distribution channels, managing disease outbreaks, and targeting improvement of communication and infrastructure). Resources can be invested in particular nodes to improve practices to control pest and disease outbreaks, leading to improvements in the seed system. We present results for the CONPAPA system as part of an ongoing project to develop general recommendations for improving seed system structure. Although we illustrate here how a seed system could potentially be resilient to removal of a key node (Fig. 5), the temporal and structural dynamics of seed systems such as CONPAPA need to be better understood to anticipate how they will react to important stressors and to develop strategies for reducing disease risk while increasing availability of improved varieties.

Specific network configurations are known to influence the probability of disease transmission and persistence (MoslonkaLefebvre et al. 2011), with the potential for important effects in plant trade networks (Pautasso et al. 2010). The network studied here has small-world properties, in that links to and from the CONPAPA management team provide shortcuts across the network. Consistent with scale-free networks, in which nodes are preferentially connected to already highly connected nodes, the CONPAPA management team and the Ambato market act as important hubs. Small-world and scalefree network structures may provide efficient spread of varieties but also may have high epidemic risk (Moslonka-Lefebvre et al. 2011). Long-distance links with the CONPAPA management team indicate the high risk of diseases entering the system from multipliers that provide seed to CONPAPA. Disease management should begin with a focus on them and on the CONPAPA facilities. It is unclear to what extent diseased ware potato could contaminate seed at these facilities. Presumably, contamination could occur for some bacterial or fungal pathogens while being less important for viral pathogens that are the main cause of seed degeneration.

Seed systems share many traits with other managed ecological systems in which there are larger-scale human institutions driving some system components (e.g., federal policy makers and federal research laboratories) and individual land managers who make choices about smaller units in the landscape (e.g., farmers or conservation managers). The approach to scenario analysis presented here can be applied to broader systems that include seed production. A fuller understanding of epidemiological risk may be gained by integrating the risk components evaluated here, due to the network structure of seed transactions and communication, with other risk components such as weather and vector movement. Local seed systems such as CONPAPA are linked internationally via plant breeding networks, through which resistance genes may be distributed (Garrett et al. 2017), with the associated need to manage connectivity for potential movement of pathogens along with germplasm. Local and regional network configurations can also determine the persistence and spread of different cultivars in the landscape, affecting farmer access to genetic resources that may be needed to respond to emerging diseases (Pautasso et al. 2013). Linking epidemiological risk assessment in local seed systems with global seed and germplasm exchange offers an opportunity to expand conceptual frameworks in epidemiology, and to integrate epidemiological concepts with other global risk factors that influence crop yield gaps. Understanding at a systems level can also inform institutional interventions via policy, training, funding, or direct management.

\section{ACKNOWLEDGMENTS}

This work received Institutional Review Board approval through the University of Florida IRB-02 number IRB201700024. We confirm that farmer participation was voluntary and personal and demographic information was protected. We appreciate input from Phytopathology reviewers for improving the manuscript. This research was undertaken as part of, and funded by, the CGIAR Research Program on Roots, Tubers and Bananas and supported by CGIAR Fund Donors (http://www.cgiar.org/about-us/ourfunders/), United States Department of Agriculture-Animal and Plant Health Inspection Service grant 11-8453-1483-CA, U.S. National Science Foundation (NSF) grant EF-0525712 as part of the joint NSF-National Institute of Health Ecology of Infectious Disease program, U.S. NSF Grant DEB0516046, and the University of Florida. We thank J. L. Brisbane and S. L. Lei for help in data management and I. Navarrete for help in testing preliminary survey drafts. The authors confirm they have no conflicts of interest.

\section{LITERATURE CITED}

Almekinders, C., Thiele, G., and Danial, D. L. 2007. Can cultivars from participatory plant breeding improve seed provision to small-scale farmers? Euphytica 153:363-372.

Andersen, K. F., Buddenhagen, C. E., Rachkara, P., Gibson, R., Kalule, S., Phillips, D. P., and Garrett, K. A. 2017. Analyzing key nodes and epidemic risk in seed networks: Sweetpotato in northern Uganda. bioRxiv Article 107359. doi:10.1101/ 107359

Bertschinger, L. 1992. Modelling of Potato Virus Pathosystems by Means of Quantitative Epidemiology: An Exemplary Case Based on Virus. Swiss Federal Institute of Technology, Zurich.

Bertschinger, L., Bühler, L., Dupuis, B., Duffy, B., Gessler, C., Forbes, G. A., Keller, E. R., Scheidegger, U. C., and Struik, P. C. 2017. Incomplete infection of secondarily infected potato plants - an environment dependent underestimated mechanism in plant virology. Front. Plant Sci. 8:1-13.

Biggs, R., Schlüter, M., Biggs, D., Bohensky, E. L., BurnSilver, S., Cundill, G., Dakos, V., Daw, T. M., Evans, L. S., Kotschy, K., Leitch, A. M., Meek, C., Quinlan, A., Raudsepp-Hearne, C., Robards, M. D., Schoon, M. L., Schultz, L., and West, P. C. 2012. Toward principles for enhancing the resilience of ecosystem services. Annu. Rev. Environ. Resour. 37:421-448.

Chadès, I., Martin, T. G., Nicol, S., Burgman, M. A., Possingham, H. P., and Buckley, Y. M. 2011. General rules for managing and surveying networks of pests, diseases, and endangered species. Proc. Natl. Acad. Sci. USA 108:8323-8328.

Choudhury, R. A., Garrett, K. A., Klosterman, S. J., Subbarao, K. V., and McRoberts, N. 2017. A framework for optimizing phytosanitary thresholds in seed systems. Phytopathology 107:1219-1228.

CIP. 2009. Catalog of Potato Varieties. International Potato Center (CIP), Lima, Peru.

Csárdi, G., and Nepusz, T. 2006. The igraph software package for complex network research. Online publication. InterJournal Complex Syst. Article 1695. http://www.interjournal.org/manuscript_abstract.php?361100992

Czajkowski, R., Perombelon, M., Jafra, S., Lojkowska, E., Potrykus, M., van der Wolf, J., and Sledz, W. 2015. Detection, identification and differentiation of Pectobacterium and Dickeya species causing potato blackleg and tuber soft rot: A review. Ann. Appl. Biol. 166:18-38.

Czajkowski, R., Pérombelon, M. C. M., van Veen, J. A., and van der Wolf, J. M. 2011. Control of blackleg and tuber soft rot of potato caused by Pectobacterium and Dickeya species: A review. Plant Pathol. 60:999-1013.

Devaux, A., Kromann, P., and Ortiz, O. 2014. Potatoes for sustainable global food security. Potato Res. 57:185-199.

Devaux, A., Ordinola, M., Hibon, A., and Flores, R., eds. 2010. El sector papa en la Región Andina: Diagnóstico y elementos para una visión estratégica (Bolivia, Ecuador y Perú). Centro Internacional de la Papa, Lima, Peru.

Fankhauser, C. 2000. Seed-Transmitted Diseases as Constraints for Potato Production in the Tropical Highlands of Ecuador. Swiss Federal Institute of Technology, Zürich.

FAO. 2006. Page 243 in: Quality Declared Seed System. FAO, Rome.

Forbes, G. A. 2012. Using host resistance to manage potato late blight with particular reference to developing countries. Potato Res. 55:205-216.

Frost, K. E., Groves, R. L., and Charkowski, A. O. 2013. Integrated control of potato pathogens through seed potato certification and provision of clean seed potatoes. Plant Dis. 97:1268-1280.

Garrett, K. A., Andersen, K. F., Asche, F., Bowden, R. L., Forbes, G. A., Kulakow, P. A., and Zhou, B. 2017. Resistance genes in global crop breeding networks. Phytopathology 107:1268-1278. 
Garrett, K. A. 2012. Information networks for plant disease: Commonalities in human management networks and within-plant signaling networks. Eur. J. Plant Pathol. 133:75-88.

Handcock, M. S., Hunter, D. R., Butts, C. T., Goodreau, S. M., and Morris, M. 2008. statnet: Software tools for the representation, visualization, analysis and simulation of network data. J. Stat. Softw. 24:1-11.

Harwood, T. D., Xu, X., Pautasso, M., Jeger, M. J., and Shaw, M. W. 2009. Epidemiological risk assessment using linked network and grid based modelling: Phytophthora ramorum and Phytophthora kernoviae in the UK. Ecol. Modell. 220:3353-3361.

Hernandez Nopsa, J. F., Daglish, G. J., Hagstrum, D. W., Leslie, J. F., Phillips, T. W., Scoglio, C., Thomas-Sharma, S., Walter, G. H., and Garrett, K. A. 2015. Ecological networks in stored grain: Key postharvest nodes for emerging pests, pathogens, and mycotoxins. BioScience 65:985-1002.

Hirpa, A., Meuwissen, M. P. M., Tesfaye, A., Lommen, W. J. M., Oude Lansink, A., Tsegaye, A., and Struik, P. C. 2010. Analysis of seed potato systems in Ethiopia. Am. J. Potato Res. 87:537-552.

Jaffee, S., Srivastava, J., and Mundial, B. 1992. Seed System Development: The Appropriate Roles of the Private and Public Sectors. World Bank, Washington, DC.

Jongejans, E., Skarpaas, O., Ferrari, M. J., Long, E. S., Dauer, J. T., Schwarz, C. M., Rauschert, E. S., Jabbour, R., Mortensen, D. A., and Isard, S. A. 2015. A unifying gravity framework for dispersal. Theor. Ecol. 8:207-223.

Kromann, P., Montesdeoca, F., and Andrade-Piedra, J. 2016. Integrating formal and informal potato seed systems in Ecuador. Pages 14-32 in: Case Studies of Roots, Tubers and Bananas Seed Systems. J. L. Andrade-Piedra, J. W. Bentley, C. Almekinders, K. Jacobsen, S Walsh, and G. Thiele, eds. CGIAR Research Program on Roots, Tubers and Bananas (RTB), Lima, Peru.

Kromann, P., Taipe, A., Perez, W. G., and Forbes, G. A. 2009. Rainfall thresholds as support for timing fungicide applications in the control of potato late blight in Ecuador and Peru. Plant Dis. 93:142-148.

Labeyrie, V., Thomas, M., Muthamia, Z. K., and Leclerc, C. 2016. Seed exchange networks, ethnicity, and sorghum diversity. Proc. Natl. Acad. Sci. USA 113:98-103.

Leeuwis, C., and Aarts, N. 2011. Rethinking communication in innovation processes: Creating space for change in complex systems. J. Agric. Educ. Ext. 17:21-36

Lybbert, T. J., and Sumner, D. A. 2012. Agricultural technologies for climate change in developing countries: Policy options for innovation and technology diffusion. Food Policy 37:114-123.

McGuire, S., and Sperling, L. 2013. Making seed systems more resilient to stress. Glob. Environ. Change 23:644-653.

McGuire, S. J., and Sperling, L. 2008. Leveraging farmers' strategies for coping with stress: Seed aid in Ethiopia. Glob. Environ. Change 18:679-688.

McRoberts, N., Hall, C., Madden, L. V., and Hughes, G. 2011. Perceptions of disease risk: From social construction of subjective judgments to rational decision making. Phytopathology 101:654-665.

Moslonka-Lefebvre, M., Finley, A., Dorigatti, I., Dehnen-Schmutz, K., Harwood, T., Jeger, M. J., Xu, X., Holdenrieder, O., and Pautasso, M. 2011. Networks in plant epidemiology: From genes to landscapes, countries, and continents. Phytopathology 101:392-403.

Mwangi, J. K., Nyende, A. B., Demo, P., and Matiru, V. N. 2008. Detection of latent infection by Ralstonia solanacearum in potato (Solanum tuberosum) using stems instead of tubers. Afr. J. Biotechnol. 7:1644-1649.

Navarrete, I., Panchi, N., Kromann, P., Forbes, G., and Andrade-Piedra, J. 2017. Health quality of seed potato and yield losses in Ecuador. bioRxiv Article 108712. doi:10.1101/108712

Okello, J., Zhou, Y., Kwikiriza, N., Ogutu, S., Barker, I., Schulte-Geldermann, E., Atieno, E., and Ahmed, J. 2016. Determinants of the use of certified seed potato among smallholder farmers: The case of potato growers in central and eastern Kenya. Agriculture 6:55.

Panchi, N., Navarrete, I., Taipe, A., Orellana, H., Pallo, E., Yumisaca, F., Montesdeoca, F., Kromann, P., and Andrade-Piedra, J. L. 2012. Pages 17-20 in: Incidencia, severidad y pérdidas causadas por plagas de la semilla se papa en Ecuador. Congreso de la Asociación Latinoamericana de la PapaALAP, Uberlandia, Brazil.
Pautasso, M., Aistara, G., Barnaud, A., Caillon, S., Clouvel, P., Coomes, O. T., Delêtre, M., Demeulenaere, E., De Santis, P., Döring, T., Eloy, L., Emperaire, L., Garine, E., Goldringer, I., Jarvis, D., Joly, H. I., Leclerc, C., Louafi, S., Martin, P., Massol, F., McGuire, S., McKey, D., Padoch, C., Soler, C., Thomas, M., and Tramontini, S. 2013. Seed exchange networks for agrobiodiversity conservation. A review. Agron. Sustain. Dev. 33:151-175.

Pautasso, M., Xu, X., Jeger, M. J., Harwood, T. D., Moslonka-Lefebvre, M., and Pellis, L. 2010. Disease spread in small-size directed trade networks: The role of hierarchical categories. J. Appl. Ecol. 47:1300-1309.

Poudel, D., Sthapit, B., and Shrestha, P. 2015. An analysis of social seed network and its contribution to on-farm conservation of crop genetic diversity in Nepal. Int. J. Biodivers. 2015: Article 312621.

R Core Team. 2017. R: A Language and Environment for Statistical Computing. R Foundation for Statistical Computing, Vienna.

Ricciardi, V. 2015. Social seed networks: Identifying central farmers for equitable seed access. Agric. Syst. 139:110-121.

RTB. 2016. Multi-stakeholder framework for intervening in RTB seed systems. RTB Working Paper 2016-1. (CGIAR Research Program on [RTB] Roots, Tubers and Bananas), Lima, Peru.

Salazar, L. F. 1996. Potato Viruses and their Control. International Potato Center, Lima, Peru.

Sanatkar, M. R., Scoglio, C., Natarajan, B., Isard, S., and Garrett, K. A. 2015. History, epidemic evolution, and model burn-in for a network of annual invasion: Soybean rust. Phytopathology 105:947-955.

Shaw, M. W., and Pautasso, M. 2014. Networks and plant disease management: Concepts and applications. Annu. Rev. Phytopathol. 52:477-493.

Sperling, L., Ortiz, O., and Thiele, G. 2013. Seed Systems. Conceptual Frameworks for Guiding Practical Interventions. CGIAR Research Program on Roots, Tubers and Bananas (RTB). RTB Working Paper 2013-1. Lima, Peru.

Sutrave, S., Scoglio, C., Isard, S. A., Hutchinson, J. M. S., and Garrett, K. A. 2012. Identifying highly connected counties compensates for resource limitations when evaluating national spread of an invasive pathogen. PLoS One 7:e37793.

Tadesse, Y., Almekinders, C. J. M., Schulte, R. P. O., and Struik, P. C. 2016. Tracing the seed: Seed diffusion of improved potato varieties through farmers' networks in Chencha, Ethiopia. Exp. Agric. 1-16.

Thiele, G. 1999. Informal potato seed systems in the Andes: Why are they important and what should we do with them? World Dev. 27:83-99.

Thiele, G., Devaux, A., Reinoso, I., Pico, H., Montesdeoca, F., Pumisacho, M., Andrade-Piedra, J., Velasco, C., Flores, P., Esprella, R., Thomann, A., Manrique, K., and Horton, D. 2011. Multi-stakeholder platforms for linking small farmers to value chains: Evidence from the Andes. Int. J. Agric. Sustain. 9:423-433.

Thomas-Sharma, S., Abdurahman, A., Ali, S., Andrade-Piedra, J., Bao, S., Charkowski, A., Crook, D., Kadian, M., Kromann, P., Struik, P., Torrance, L., Garrett, K. A., and Forbes, G. A. 2016. Seed degeneration in potato: The need for an integrated seed health strategy to mitigate the problem in developing countries. Plant Pathol. 65:3-16.

Thomas-Sharma, S., Andrade-Piedra, J., Carvajal Yepes, M., Hernandez Nopsa, J. F., Jeger, M. J., Jones, R. A. C., Kromann, P., Legg, J. P., Yuen, J., Forbes, G. A., and Garrett, K. A. 2017. A risk assessment framework for seed degeneration: Informing an integrated seed health strategy for vegetatively propagated crops. Phytopathology. 107:1123-1135.

Toth, I. K., Van Der Wolf, J. M., Saddler, G., Lojkowska, E., Hélias, V., Pirhonen, M., and Elphinstone, J. G. 2011. Dickeya species: An emerging problem for potato production in Europe. Plant Pathol. 60:385-399.

Violon, C., Thomas, M., and Garine, E. 2016. Good year, bad year: Changing strategies, changing networks? A two-year study on seed acquisition in northern Cameroon. Ecol. Soc. 21:34.

Welch, D., Bansal, S., and Hunter, D. R. 2011. Statistical inference to advance network models in epidemiology. Epidemics 3:38-45.

Xing, Y., Hernandez Nopsa, J., Andrade-Piedra, J., Beed, F., Blomme, G., Carvajal Yepes, M., Coyne, D., Forbes, G., Kreuze, J., Kroschel, J., Kumar, L., Legg, J., Parker, M., Schulte-Geldermann, E., and Garrett, K. A. 2017. Global cropland connectivity: A risk factor for invasion and saturation by emerging pathogens and pests. bioRxiv Article 106542. doi:10.1101/106542 